\title{
Clinical pharmacokinetics of penicillins in the neonate: a review of the literature
}

\author{
G. M. Pacifici • J. Labatia • H. Mulla • I. Choonara
}

Received: 1 July 2008 / Accepted: 26 August 2008 / Published online: 23 September 2008

(C) Springer-Verlag 2008

\begin{abstract}
Background Sepsis is common in neonates and a major cause of morbidity and mortality. Sixty percent of preterm neonates receive at least one antibiotic during the first week of life, with penicillins being the most frequently administered antibiotics. The clearance $(\mathrm{Cl})$, serum half-life $\left(\mathrm{t}_{1} / 2\right)$ and volume of distribution (Vd) of penicillins are different in the neonate than in the adult. As such, the pharmacokinetics of penicillins need be studied in neonates in order to optimise therapy in this age class with these drugs.

Objectives The aim of this study was to review the published data on the pharmacokinetics of penicillins in the neonate in order to provide a critical analysis of the literature and, consequently, a useful tool in the hands of the physician.

Methods The bibliographic search was performed electronically using the PubMed and EMBASE databases as search engines. An initial search was performed with the keywords
\end{abstract}

G. M. Pacifici $(\bowtie)$

Department of Neurosciences, Section of Pharmacology,

Medical School,

Via Roma 55,

56126 Pisa, Italy

e-mail: pacifici@biomed.unipi.it

J. Labatia

Derbyshire Children's Hospital,

Derby, UK

H. Mulla

Centre for Therapeutic Evaluation of Drugs in Children,

University Hospitals of Leicester,

Leicester, UK

I. Choonara

Academic Division of Child Health, University of Nottingham,

Derbyshire Children's Hospital,

Derby, UK "pharmacokinetics", "penicillins" and "neonates". Secondly, other searches were performed using the keywords "pharmacokinetics" and "neonates", followed by the name of a single antibiotic. The search included articles up to 2007.

Results There have been few pharmacokinetic studies on the use of penicillins in neonates. The results from those few studies that have been carried out suggest that the $\mathrm{Cl}$ is reduced and $t_{1 / 2}$ prolonged in the neonate as compared with the more mature infant. There is little variation in $\mathrm{Vd}$ during the first week of life. In the premature neonate, $\mathrm{Cl}$ is reduced compared to the full-term infant. As postnatal age proceeds, the $\mathrm{Cl}$ of penicillins increases.

Conclusions More pharmacokinetic studies are required to provide a sound scientific basis for planning a dosage regimen with penicillins in the neonate.

Keywords Amoxicillin · Ampicillin · Azlocillin .

Clavulanic acid · Flucloxacillin · Methicillin · Mezlocillin .

Neonate $\cdot$ Penicillins $\cdot$ Pharmacokinetics .

Piperacillin and ticarcillin

\section{Introduction}

Neonatal sepsis is common in neonates and can be acquired at delivery passing through the birth canal or later from hospital-acquired sources [1]. Infection is a major cause of morbidity and mortality, especially for those who are preterm and low birth weight. Mortality occurs in 10-20\% of those infants with neonatal sepsis, with sequelae occurring in $25-30 \%$ of the infants who survive [2]. An evaluation of the use of antibiotics revealed that $60 \%$ of preterm neonates received at least one antibiotic during the first week of life [3], with over half of the antibiotics being 
penicillins [3]. The extensive use of penicillins in the newborn infants requires that the pharmacokinetics (PK) of these drugs should be studied in this age group.

Penicillins are water-soluble compounds and are mainly eliminated by the kidney. Renal glomerular filtration and tubular secretion are reduced in the newborn infant [4]. The reduced renal elimination affects the disposition of penicillins, and their clearance $(\mathrm{Cl})$ is reduced in the newborn as compared to children. The $\mathrm{Cl}$ is even lower in preterm neonates. The volume of distribution (Vd) of penicillins is greater in the neonate than in the adult because of the larger water body content in the newborn infant. In the latter, $75 \%$ of the total body weight is constituted by water [4].

The aim of this study was to review the PK of penicillins in neonates. The PK parameters of penicillins are summarised in Tables 1, 2, 3, 4, 5, 6, 7. In this study, the penicillins have been divided into the following groups:

1. Benzylpenicillin (penicillin $G$ ) and phenoxymethylpenicillin (penicillin $\mathrm{V}$ )

2. Broad spectrum penicillins-ampicillin, amoxicillin and co-amoxiclav (amoxicillin and clavulanic acid)

3. Penicillinase resistant penicillin (flucloxacillin)

4. Antipseudomonal penicillins-azlocillin, mezlocillin, ticarcillin and piperacillin

\section{Bibliographic search}

The bibliographic search was performed electronically using the PubMed and EMBASE databases as search engines; December 2007 was the cutoff point. Initially, a search was performed with the following keywords "pharmacokinetics", "penicillins" and "neonates" with the limit of "human". Secondly, other searches were performed using the following keywords "pharmacokinetics" and "neonates", followed by the name of any one of the following antibiotics: penicillin, ampicillin, amoxicillin, azlocillin, carbenicillin, clavulanic acid, flucloxacillin, mezlocillin, piperacillin, pivmecillinam and ticarcillin. The bibliography of each article was read carefully, and the selected articles were critically read.

\section{Benzylpenicillin (penicillin G)}

There have been three separate studies on benzylpenicillin (penicillin G) [5-7] (Table 1). The first detailed study of the PK of penicillin in neonates [5] was performed in the early 1970s in 47 newborn infants (no details are given of the gestation except that the group included both preterm and term neonates). The half-life ( $\left.\mathrm{t}_{1 / 2}\right)$ decreased from $3.2 \mathrm{~h}$ in the first week of life to $1.4 \mathrm{~h}$ in week 3 . A study in 18 very low birth weight (VLBW) neonates confirmed that the $t_{1 / 2}$ in VLBW neonates is longer $(4.2 \mathrm{~h})$, and these authors concluded that $15 \mathrm{mg} \mathrm{kg}^{-1} 12 \mathrm{~h}^{-1}$ results in serum concentrations above the minimum inhibitory concentration for $90 \%$ of group B streptococci strains $\left(\mathrm{MIC}_{90}\right)$ [6]. Another group of researchers suggested that $30 \mathrm{mg} \mathrm{kg}^{-1}$ $12 \mathrm{~h}^{-1}$ was adequate [7].

\section{Broad spectrum penicillins}

\section{Ampicillin}

Original studies of ampicillin PK in neonates did not provide extensive details of either gestational age (GA) or weight [8-12], but instead focused on $t_{1 / 2}$ and peak plasma concentrations (Table 2). These studies confirmed that preterm neonates have a longer $t_{1 / 2}(4-5.5 \mathrm{~h})[11,12]$ and that the $t_{1 / 2}$ decreases rapidly with postnatal age during the first few weeks of life [12].

\section{Amoxicillin}

The studies of ampicillin PK have been used to extrapolate recommended doses for amoxicillin, which is a derivative

Table 1 Pharmacokinetic parameters of benzylpenicillin

\begin{tabular}{|c|c|c|c|c|c|c|c|c|c|c|}
\hline \multirow[t]{2}{*}{ GA (weeks) } & \multirow[t]{2}{*}{ PNA (days) } & \multirow[t]{2}{*}{ Weight $(\mathrm{kg})$} & \multirow[t]{2}{*}{$n$} & \multirow[t]{2}{*}{ Dose $\left(\mathrm{mg} \mathrm{kg}^{-1}\right)$} & \multirow[t]{2}{*}{$\mathrm{Cl}\left(\mathrm{ml} \mathrm{min}{ }^{-1}\right)$} & \multirow[t]{2}{*}{$\mathrm{Vd}\left(1 \mathrm{~kg}^{-1}\right)$} & \multirow[t]{2}{*}{$t_{1 / 2}(h)$} & \multicolumn{2}{|c|}{ Plasma concentration $\left(\mu \mathrm{g} \mathrm{ml}^{-1}\right)$} & \multirow[t]{2}{*}{ Reference } \\
\hline & & & & & & & & Peak & Trough & \\
\hline$?$ & $0-6$ & $?$ & 24 & 10-30 IM & - & - & 3.2 & $22-36$ & - & 5 \\
\hline$?$ & $>14$ & $?$ & 6 & $10 \mathrm{IM}$ & & & 1.4 & - & - & 5 \\
\hline$<28$ & $0-3$ & $<1.2$ & 8 & 30 bid & $1.2 \mathrm{~kg}^{-1}$ & 0.41 & 3.8 & 146 & 7 & 6 \\
\hline$<28$ & $0-3$ & $<1.2$ & 9 & 15 bid & $1.5 \mathrm{~kg}^{-1}$ & 0.65 & 4.6 & 59 & 3 & 6 \\
\hline$<32$ & 3 & $0.6-2.0$ & 20 & 30 bid & 1.72 & $0.5^{*}$ & 3.9 & - & - & 7 \\
\hline
\end{tabular}

GA, Gestational age; PNA, post-natal age; $\mathrm{Cl}$, clearance; Vd volume of distribution (given in litres); $\mathrm{t}_{1 / 2}$, half-life; IM, intramuscular; bid, twice daily

Values are given as the mean or range 
Table 2 Pharmacokinetic parameters of ampicillin

\begin{tabular}{|c|c|c|c|c|c|c|c|}
\hline GA (weeks) & PNA (days) & Weight (kg) & $n$ & Dose $\left(\mathrm{mg} \mathrm{kg}^{-1}\right)$ & $t_{1 / 2}(h)$ & Peak concentration $\left(\mu \mathrm{g} \mathrm{ml}^{-1}\right)$ & Reference \\
\hline$>37$ & $2-4$ & $>2.5$ & 3 & 50-100 IV infusion & 2.2 & - & 9 \\
\hline$>37$ & $1-7$ & $?$ & \} 27 & $50-100$ IM bid & 3.9 & $36-257$ & 11 \\
\hline$<37$ & $1-7$ & $?$ & & 50-100 IM bid & 5.5 & $78-293$ & 11 \\
\hline$?$ & $7-35$ & $?$ & 4 & $50 \mathrm{IM}$ tid & 1.6 & 58 & 11 \\
\hline$<37$ & $2-7$ & $<2$ & 9 & $10 \mathrm{IM}$ & 4.0 & $13-19$ & 12 \\
\hline$<37$ & $8-14$ & $<2$ & 6 & $10 \mathrm{IM}$ & 2.8 & $13-19$ & 12 \\
\hline$<37$ & $15-30$ & $<2$ & 11 & $10 \mathrm{IM}$ & 1.7 & $13-19$ & 12 \\
\hline$<37$ & $61-68$ & $<2$ & 9 & $10 \mathrm{IM}$ & 1.6 & $13-19$ & 12 \\
\hline
\end{tabular}

tid, three times daily; IV, intravenous

Values are given as the mean or range.

of ampicillin with a greater bioavailability following oral administration. There have been a total of six amoxicillin PK studies in neonates [13-18] (Table 3). Preterm infants $\left(<32\right.$ weeks GA) have a longer $t_{1 / 2}(6.7 \mathrm{~h})$ [13] than term neonates $(3.7 \mathrm{~h})[13,18]$.

A study of 40 preterm neonates $(<32$ weeks GA) looked at the effects of gentamicin on amoxicillin $\mathrm{Cl}$ and found that there was a significant decrease of $25 \%$ in amoxicillin $\mathrm{Cl}$ with co-administered gentamicin [14]. They also found a twofold increase in the $\mathrm{Vd}$ of amoxicillin and that the $t_{1 / 2}$ in preterm babies was longer when given with gentamicin $(6.9 \mathrm{~h})$ than when given without concurrent gentamicin $(5.2 \mathrm{~h})$.

Two studies looked at the PK and dosing of amoxicillin in neonates $[13,15]$. In one study, the authors recommended a dose of $15 \mathrm{mg} \mathrm{kg}^{-1} 8 \mathrm{~h}^{-1}$ for GA $<34$ weeks and $20 \mathrm{mg}$ $\mathrm{kg}^{-1} 8 \mathrm{~h}^{-1}$ for GA $>34$ weeks [15]. The authors of the second study suggested that preterm infants with GA $<32$ weeks in the first week of life should receive a maximum amoxicillin dose of $25 \mathrm{mg} \mathrm{kg}^{-1} 12 \mathrm{~h}^{-1}$ [13]. In both studies, the $\mathrm{Cl}$ and $\mathrm{Vd}$ of amoxicillin were found to increase with GA and body weight.

The most recent study looked at the effects of postnatal age and found that the $\mathrm{Cl}$ was greater in neonates $>9$ days old $\left(3.0 \mathrm{ml} \mathrm{min}{ }^{-1} \mathrm{~kg}^{-1}\right)$ [17] than had been shown in previous studies in neonates of a similar gestation $\left(1.6 \mathrm{ml} \mathrm{min}^{-1} \mathrm{~kg}^{-1}\right)$ [15]. Similarly, the $t_{1 / 2}$ was considerably shorter $(3 \mathrm{~h}$ vs. $5.2 \mathrm{~h}$ ). These authors recommended an amoxycillin dose of $40 \mathrm{mg} \mathrm{kg}^{-1} 8 \mathrm{~h}^{-1}$ for infants $>9$ days post-natal age (PNA).

Cardiopulmonary bypass surgery decreased the mean plasma concentration of amoxicillin by $36 \%$, from 73 to $47 \mu \mathrm{g} \mathrm{ml}^{-1}$ [16]. The GA of these patients was not stated, but they appear to have been term infants. It is therefore difficult to compare these patients with a similar group in terms o cardiopulmonary bypass.

\section{Penicillinase-resistant penicillins}

\section{Flucloxacillin}

There have only been three studies of the PK of flucloxacillin in neonates $[16,19,20]$ (Table 4). A Dutch group that looked at both preterm and term neonates suggested that the current dosage regime $\left(25-50 \mathrm{mg} \mathrm{kg}^{-1}\right.$ every 8 or $12 \mathrm{~h}$ ) did not result in effective plasma concentrations for the treatment of Staphylococcus aureus in one third of the neonates treated [19]. They therefore suggested an initial dose of $25 \mathrm{mg} \mathrm{kg}^{-1} 4 \mathrm{~h}^{-1}$ for all

Table 3 Pharmacokinetic parameters of amoxicillin

\begin{tabular}{|c|c|c|c|c|c|c|c|c|c|c|}
\hline $\begin{array}{l}\text { GA } \\
\text { (weeks) }\end{array}$ & $\begin{array}{l}\text { PNA } \\
\text { (days) }\end{array}$ & $\begin{array}{l}\text { Weight } \\
(\mathrm{kg})\end{array}$ & $n$ & $\begin{array}{l}\text { Dose } \\
\left(\mathrm{mg} \mathrm{kg}^{-1}\right)\end{array}$ & 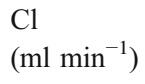 & $\begin{array}{l}\mathrm{Vd} \\
\left(1 \mathrm{~kg}^{-1}\right)\end{array}$ & $t_{1 / 2}(h)$ & $\begin{array}{l}\text { Peak concentration } \\
\left(\mu \mathrm{g} \mathrm{ml}^{-1}\right)\end{array}$ & $\begin{array}{l}\text { Trough concentration } \\
\left.(\mu \mathrm{g} \mathrm{ml})^{-1}\right)\end{array}$ & Reference \\
\hline$<32$ & 3 & $<1.5$ & 17 & $25 \mathrm{BD}$ & 1.0 & 0.67 & 6.7 & 54 & 16 & 13 \\
\hline$\leq 32$ & $1-3$ & $<1.5$ & 40 & $50 \mathrm{BD}$ & $1.3 \mathrm{~kg}^{-1}$ & 0.68 & - & 74 & - & 14 \\
\hline $25-42$ & $0-3$ & 2.3 & 150 & 30 & $1.6 \mathrm{~kg}^{-1}$ & 0.65 & 5.2 & 101 & 21 & 15 \\
\hline $26-41$ & $10-52$ & 2.3 & 32 & $50-100$ & $3.0 \mathrm{~kg}^{-1}$ & 0.66 & 3.0 & - & - & 17 \\
\hline$>37$ & $1-3 ?$ & $?$ & 16 & 50 & - & - & - & 38 & 13 & 18 \\
\hline$<37$ & $1-3 ?$ & $?$ & 7 & 50 & - & - & - & 59 & 19 & 18 \\
\hline $\mathrm{n} / \mathrm{a}$ & $3-60^{a}$ & 3.6 & 11 & 30 TDS & $1.4^{\mathrm{a}}$ & $0.4^{\mathrm{a} *}$ & $3.1^{\mathrm{a}}$ & $\mathrm{n} / \mathrm{a}$ & $\mathrm{n} / \mathrm{a}$ & 16 \\
\hline
\end{tabular}

n/a, Not available

Values are given as the mean or range

${ }^{\text {a }}$ Patients on cardiopulmonary bypass 
Table 4 Pharmacokinetic parameters of flucloxacillin

\begin{tabular}{|c|c|c|c|c|c|c|c|c|c|}
\hline GA (weeks) & PNA (days) & Weight (kg) & $n$ & Dose $\left(\mathrm{mg} \mathrm{kg}^{-1}\right)$ & $\mathrm{Cl}\left(\mathrm{ml} \mathrm{min}{ }^{-1} \mathrm{~kg}^{-1}\right)$ & $\operatorname{Vd}\left(1 \mathrm{~kg}^{-1}\right)$ & $t_{1 / 2}(h)$ & Peak concentration $\left(\mu \mathrm{g} \mathrm{ml}^{-1}\right)$ & Reference \\
\hline $26-42$ & $0-44$ & $0.4-4.1$ & 55 & $25-50 \mathrm{bid} / \mathrm{tid}$ & 3.0 & 0.54 & 2.6 & $38-114$ & 19 \\
\hline $33-41$ & $?$ & $?$ & 9 & 50 & 0.7 & 0.28 & 4.6 & - & 20 \\
\hline$?$ & $3-60$ & 3.6 & 11 & 30 & $2.0^{\mathrm{a}}$ & $0.45^{\mathrm{a}}$ & $2.6^{\mathrm{a}}$ & $15-70^{\mathrm{a}}$ & 16 \\
\hline
\end{tabular}

Values are given as the mean or range

${ }^{\text {a }}$ Patients on cardiopulmonary bypass

neonates. This is in contrast to the 12 -h recommendation for neonates in the first week of life in formularies such as the British National Formulary for Children (BNFC) [21]. A small study of nine neonates also suggested that the $t_{1 / 2}$ was related to GA [20]. Cardiopulmonary bypass decreased the plasma concentrations of flucloxacillin by over $40 \%$, from 75 to $43 \mu \mathrm{g} \mathrm{ml}^{-1}$ [16].

\section{Antipseudomonal penicillins}

Within the UK, the two main antipseudomonal penicillins are piperacillin and ticarcillin. Ticarcillin is only available in combination with clavulanic acid. In other countries, acylureidopenicillins such as azlocillin and mezlocillin are used.

\section{Azlocillin}

There have been two PK studies of azlocillin in neonates $[22,23]$, both of which were performed in Germany in the 1980s (Table 5). The first study involved 53 neonates (average GA 34 weeks) [22]. The authors of this study recommended $50 \mathrm{mg} \mathrm{kg}^{-1} 12 \mathrm{~h}^{-1}$ for preterm neonates in the first 7 days of life and $100 \mathrm{mg} \mathrm{kg}^{-1} 12 \mathrm{~h}^{-1}$ for full term neonates in the first 7 days of life. A subsequent study suggested no difference in $t_{1 / 2}$ in preterm and term infants [23]. The GA of the preterm infants, however, was not given (their weights ranged from 1.77 to $2.5 \mathrm{~kg})$.

\section{Mezlocillin}

There wre two PK studies in neonates in the USA in the 1980s (Table 6). One involved treatment with mezlocillin and an aminoglycoside [24]. The majority of the neonates (34) were in the first week of life and of these, 30 were $<34$ weeks GA. The mezlocillin serum concentration was influenced by the weight, route of administration and concurrent administration of an aminoglycoside. Clearance increased with increasing GA and weight. There was also a direct relationship between $\mathrm{Vd}$ and body weight. However, there was no significant correlation between $t_{1 / 2}$ and weight. The clearance was less when mezlocillin was given concomitantly with an aminoglycoside. The authors presented individual data for all the PK parameters in relation to weight but, unfortunately, not in relation to GA. They suggested a dosage of $75 \mathrm{mg} \mathrm{kg}^{-1}$ every $8-12 \mathrm{~h}$.

The other study involved 47 neonates, the majority of whom were premature and $<7$ days old [25]. This group recommended that mezlocillin be administered at $12-\mathrm{h}$ intervals $\left(75 \mathrm{mg} \mathrm{kg}^{-1}\right)$ to preterm infants in the first week of life, at 8 -h intervals to preterm infants $>7$ days and term infants $<7$ days. They also recommended the administration of 6-h doses to term infants $>7$ days of age [25].

Ticarcillin

There have been three PK studies of ticarcillin in neonates where it has been given in combination with clavulanic acid

Table 5 Pharmacokinetic parameters of azlocillin

\begin{tabular}{|c|c|c|c|c|c|c|c|c|c|c|}
\hline $\begin{array}{l}\text { GA } \\
\text { (weeks) }\end{array}$ & $\begin{array}{l}\text { PNA } \\
\text { (days) }\end{array}$ & $\begin{array}{l}\text { Weight } \\
(\mathrm{kg})\end{array}$ & $n$ & $\begin{array}{l}\text { Dose } \\
\left(\mathrm{mg} \mathrm{kg}^{-1}\right)\end{array}$ & 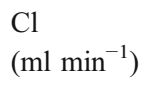 & $\begin{array}{l}\mathrm{Vd} \\
\left(1 \mathrm{~kg}^{-1}\right)\end{array}$ & $\mathrm{t}_{1 / 2}(\mathrm{~h})$ & $\begin{array}{l}\text { Peak concentration } \\
\left(\mu \mathrm{g} \mathrm{ml}^{-1}\right)\end{array}$ & $\begin{array}{l}\text { Trough concentration } \\
\left(\mu \mathrm{g} \mathrm{ml}^{-1}\right)\end{array}$ & Reference \\
\hline$<37$ & $?$ & 1.8 & 7 & $50 \mathrm{BD} \mathrm{IM} / \mathrm{IV}$ & $\mathrm{n} / \mathrm{a}$ & 0.34 & 4.4 & 122 & 20 & 22 \\
\hline $37-42$ & $?$ & $?$ & 27 & $50 \mathrm{BD} \mathrm{IM} / \mathrm{IV}$ & $\mathrm{n} / \mathrm{a}$ & 0.30 & 2.6 & 128 & 27 & 22 \\
\hline $37-42$ & $?$ & $?$ & 22 & $100 \mathrm{BD} \mathrm{IM} / \mathrm{IV}$ & $\mathrm{n} / \mathrm{a}$ & 0.30 & 2.6 & 260 & 17 & 22 \\
\hline$<37$ & $2-26$ & 2.1 & 12 & $50 \mathrm{IV}$ & 3.7 & 0.33 & 2.5 & - & - & 23 \\
\hline $37-42$ & $2-26$ & 3.1 & 13 & $50 \mathrm{IV}$ & 4.9 & 0.32 & 2.6 & - & - & 23 \\
\hline
\end{tabular}

Values are given as the mean or range 
Table 6 Pharmacokinetic parameters of mezlocillin following $75 \mathrm{mg} \mathrm{kg}^{-1}$ (IV or IM)

\begin{tabular}{|c|c|c|c|c|c|c|c|c|c|}
\hline $\begin{array}{l}\text { GA } \\
\text { (wk) }\end{array}$ & $\begin{array}{l}\text { PNA } \\
\text { (days) }\end{array}$ & $\begin{array}{l}\text { Weight } \\
(\mathrm{kg})\end{array}$ & $n$ & $\begin{array}{l}\mathrm{Cl} \\
\left(\mathrm{mg} \mathrm{kg}^{-1}\right)\end{array}$ & $\begin{array}{l}\mathrm{Vd} \\
\left(1 \mathrm{~kg}^{-1}\right)\end{array}$ & $t_{1 / 2}(h)$ & $\begin{array}{l}\text { Peak concentration } \\
\left(\mu \mathrm{g} \mathrm{ml}^{-1}\right)\end{array}$ & $\begin{array}{l}\text { Trough concentration } \\
\left(\mu \mathrm{g} \mathrm{ml}^{-1}\right)\end{array}$ & Reference \\
\hline $26-40$ & $1-72$ & $0.6-3.0$ & 53 & $1.3^{\mathrm{a}}$ & 0.38 & 3.7 & 231 & 43 & 24 \\
\hline$<38$ & $0-7$ & $\mathrm{n} / \mathrm{a}$ & 26 & $9.3^{\mathrm{b}}$ & 0.34 & 4.5 & 252 & 72 & 25 \\
\hline $38-42$ & $0-7$ & $\mathrm{n} / \mathrm{a}$ & 13 & $12.3^{\mathrm{b}}$ & 0.37 & 3.0 & 272 & 34 & 25 \\
\hline $38-42$ & $>7$ & $\mathrm{n} / \mathrm{a}$ & 8 & $21.0^{\mathrm{b}}$ & 0.42 & 1.8 & 139 & 9 & 25 \\
\hline
\end{tabular}

Values are given as the mean or range

${ }^{\mathrm{a}} \mathrm{ml} \mathrm{min}{ }^{-1} \mathrm{~kg}^{-1}$

${ }^{\mathrm{b}} \mathrm{ml} \mathrm{min}^{-1}$ per $1.73 \mathrm{~m}^{2}$

[26-28] (Table 7). The first study looked at the use of prophylactic ticarcillin and clavulanic acid (ratio 15:1) in neonates from 25 to 39 weeks GA. As well as studying the PK of ticarcillin, these researchers also looked at the PK of clavulanic acid [26]. A subsequent study looked at a 25:1 combination of ticarcillin and clavulanic acid and showed that term neonates had a shorter $t_{1 / 2}(2.7 \mathrm{~h})$ than preterm infants $(4.2 \mathrm{~h})$ [27]. The third study looked at a different ratio (30:1 ticarcillin-clavulanic acid) [28] and found a similar $t_{1 / 2}$ to that of previous studies but also calculated $\mathrm{Cl}$. These authors also suggested that it would be more appropriate to use a dosage of $50 \mathrm{mg} \mathrm{kg}^{-1} 6 \mathrm{~h}^{-1}$ than the $75 \mathrm{mg} \mathrm{kg}^{-1} 12 \mathrm{~h}^{-1}$ used in their study.

\section{Piperacillin}

There has only been one study of the PK of piperacillin in neonates [29]. This was a study of 28 neonates (GA 2940 weeks), and thee authors confirmed that as the GA increased, the $t_{1 / 2}$ decreased and $\mathrm{C} 1$ increased. They suggested that $75 \mathrm{mg} \mathrm{kg}^{-1}$ of piperacillin be administered a 12-h intervals in the first week of life and at 8-h intervals from day 7 onwards in preterm neonates; for full term neonates they recommended a dose of $75 \mathrm{mg} \mathrm{kg}^{-1} 8 \mathrm{~h}^{-1}$ in the first week of life and at 6-h intervals from day 7 .

\section{Pharmacokinetic-pharmacodynamic relationship}

Antibiotic pharmacokinetic-pharmacodynamic (PD) relationships integrate a knowledge of the microbiology with parameters of drug exposure, such as peak concentrations (Cmax) or area under the curve (AUC) [30]. By relating exposure parameters to a measure of antibiotic potency (e.g. minimum inhibitory concentration for the pathogen in question), the dose can be optimised and the desired microbiological or clinical effect (e.g. eradication of infection) can be achieved. Such rational approaches to selecting doses also enable the desired response to be achieved in the largest proportion of patients-i.e. high probability of therapeutic success and low probability of toxicity [31]. Furthermore, by defining the antibiotic PKPD relationship, sub-optimal antibiotics and doses can be avoided, thereby minimising the emergence of resistance and improving outcome for patients [32].

Specific PK/PD parameters [e.g. peak/MIC, AUC/MIC ratio and time above MIC ( $\mathrm{T}>\mathrm{MIC})]$ have all been shown to be major determinants of in vivo activity [30]. For a given antibiotic class, the specific PK/PD parameter correlating with efficacy is largely dependent on whether bacterial killing is concentration- or time-dependent. Penicillins (and other beta-lactams) are time-dependent

Table 7 Pharmacokinetic parameters of ticarcillin

\begin{tabular}{|c|c|c|c|c|c|c|c|c|c|c|}
\hline $\begin{array}{l}\text { GA } \\
\text { (weeks) }\end{array}$ & $\begin{array}{l}\text { PNA } \\
\text { (days) }\end{array}$ & $\begin{array}{l}\text { Weight } \\
(\mathrm{kg})\end{array}$ & $n$ & $\begin{array}{l}\text { Dose } \\
\left(\mathrm{mg} \mathrm{kg}^{-1}\right)\end{array}$ & 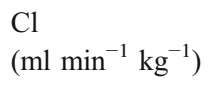 & $\begin{array}{l}\mathrm{Vd} \\
\left(1 \mathrm{~kg}^{-1}\right)\end{array}$ & $t_{1 / 2}(h)$ & $\begin{array}{l}\text { Peak concentration } \\
\left(\mu \mathrm{g} \mathrm{ml} l^{-1}\right)\end{array}$ & $\begin{array}{l}\text { Trough concentration } \\
\left(\mu \mathrm{g} \mathrm{ml} l^{-1}\right)\end{array}$ & Reference \\
\hline 31 & $?$ & 1.7 & 24 & 75 bid & - & - & 4.5 & 183 & 43 & 26 \\
\hline $34-36$ & $?$ & 2.4 & 7 & 83 tid & - & 0.34 & 4.2 & 279 & 64 & 27 \\
\hline$>37$ & $?$ & 3.3 & 7 & 100 tid & - & 0.27 & 2.7 & 405 & 56 & 27 \\
\hline 30 & 9 & 1.2 & 11 & 75 bid & 0.78 & 0.26 & 4.2 & 976 & 42 & 28 \\
\hline
\end{tabular}

Values are given as the mean or range 
agents, meaning that it is important that the dosing regimen maximises the T $>$ MIC of the target organism. A T > MIC of $30-40 \%$ is acceptable in adults, but a higher level of 40 $50 \%$ is required in neonates [33]. Concentrations higher than the MIC do not greatly increase bacterial kill [30].

The optimum penicillin dose for treating an infection is one that balances the risk (adverse effect)-benefit (efficacy) profile. It is clear that in order to be able to optimise penicillin dosing in neonates, a knowledge of the PK correlated with a measure of microbiological potency is of importance in developing a dosing regimen that maintains serum penicillin levels greater than the MIC for at least 40 $50 \%$ of the dosing interval.

\section{Discussion}

Penicillins are a key component of drug therapy in neonatal intensive care units in both developed and developing countries [34, 35] and have been used extensively for several decades. They play a crucial role in the management of Group B streptococcal disease, which remains a significant problem [36]. The efficacy of penicillin in the prevention of neonatal Group B streptococcal disease has been demonstrated in several randomised clinical trials [37, 38]. Retrospective studies have shown the benefit of ampicillin and aminoglycoside combination therapy for the management of neonatal septicaemia and meningitis [39].

It is however surprising that there have been few PK studies performed. Those studies that have been carried out show that both GA and PNA have an impact on clearance and hence plasma $t_{1 / 2}[5,11,12,15,17,20,27,29]$. Most of these PK studies have been classical PK studies where several blood samples were taken from each infant. There have only been five population PK studies, and these have involved benzylpenicillin [7], amoxicillin [14, 15, 17] and flucloxacillin [19]. The findings from the population PK studies are consistent with those involving traditional sampling.
Antibiotics in the neonatal period have been associated with drug toxicity-notably kernicterus in association with the use of sulphonamides and cardiovascular collapse in association with the use of chloramphenicol [40]. Neurotoxicity in association with the use of ampicillin has been reported [41]. The combination of ampicillin and cefotaxime has been associated with a greater mortality than the combination of ampicillin and gentamicin in neonates with sepsis [42]. The minimal toxicity associated with penicillins in comparison with other antibiotics, such as aminoglycosides and second- and third-generation cephalosporins is probably one of the reasons why there have been very few PK studies.

An additional reason is the fact that intravenous formulations of the penicillins are cheap and there are no longer patents on these medicines. Therefore, no major pharmaceutical company is keen to promote clinical trials where the PK is studied in both very preterm and term infants. There is, however, considerable inter-individual variability in the PK of penicillins in the neonatal period. The clearance of amoxicillin in one study showed a five fold inter-individual variation [15].

The dosage regime for penicillins is shown in Table 8 . This is based on the BNFC and the Neonatal Formulary (NF) [43]. The dose is constant for neonates of all gestations, and the frequency of administration is twice daily in the first 7 days of life and thereafter three times daily. There is a considerable dose variation for both benzylpenicillin and flucloxacillin and, to a lesser extent, for ampicillin and amoxicillin. The recommended dose is based on the type of infection. It is clear that the doses recommended in the BNFC and the NF are not entirely evidence based and do not take into account GA.

We feel further research is required to ensure that the doses recommended for the treatment of sepsis in neonates are evidence-based. Such research may result in an improvement in the efficacy of penicillins in the neonatal period, as treatment failure has been reported in $20 \%$ of

Table 8 Recommended doses of penicillins in the British National Formulary for Children (BNFC) and the Neonatal Formulary (NF)

\begin{tabular}{|c|c|c|c|c|}
\hline \multirow[t]{2}{*}{ Drug } & \multicolumn{2}{|c|}{ Dose $(\mathrm{mg} / \mathrm{kg})$} & \multicolumn{2}{|c|}{ Frequency in relation to age } \\
\hline & BNFC & NF & $<7$ days & $7-28$ days \\
\hline Benzylpenicillin & $25-75$ & $30-60$ & bid & $\mathrm{tid}^{\mathrm{b}}$ \\
\hline Ampicillin & $30-50$ & $50-100$ & bid & $\mathrm{tid}^{\mathrm{a}}$ \\
\hline Amoxicillin & $30-50$ & $50-100$ & bid & $\mathrm{tid}^{\mathrm{b}}$ \\
\hline Flucloxacillin & $25-100$ & $50-100$ & bid & $\mathrm{tid}^{\mathrm{a}}$ \\
\hline Ticarcillin & 80 & - & bid & tid \\
\hline Piperacillin & 90 & - & bid & tid \\
\hline
\end{tabular}

${ }^{a}$ tid for 7-21 days and qid (four times daily) for 21-28 days

${ }^{\mathrm{b}} \mathrm{NF}$ only: tid for 7-21 days and qid for 21-28 days 
neonatal infections, despite the organisms being sensitive to the antibiotics [39].

\section{References}

1. Sanghvi KP, Tudehope DI (1996) Neonatal bacterial sepsis in a neonatal intensive care unit: a 5 year analysis. J Paediatr Child Health 32:333-338

2. Siegel JD, McCracken GM (1981) Sepsis Neonatorum. New Engl J Med 304:642-647

3. Bonati M (1988) Early neonatal drug utilisation in preterm newborns in neonatal intensive cure units: Italian collaborative group on preterm delivery. Dev Pharmacol Ther 11:1-7

4. Paap CM, Nahata MC (1990) Clinical pharmacokinetics of antibacterial drugs in neonates. Clin Pharmacokinet 19:280-318

5. McCracken GH Jr, Ginsberg C, Chrane DF, Thomas ML, Horton LJ (1973) Clinical pharmacology of penicillin in newborn infants. J Pediatr 82:692-698

6. Metsvaht T, Oselin K, Ilmoja ML, Anier K, Lutsar I (2007) Pharmacokinetics of penicillin $\mathrm{G}$ in very-low-birth-weight neonates. Antimicrob Agents Chemother 51:1995-2000

7. Muller AE, DeJongh J, Bult Y et al (2007) Pharmacokinetics of penicillin $G$ in infants with a gestational age of less than 32 weeks. Antimicrob Agents Chemother 51:3720-3725

8. Hermans J, Dressen O, Sorgedrager N, Spoor M (1975) Pharmacokinetic analysis of ampicillin concentration in neonates: comparison of two pharmacokinetic models and of two numerical methods. Arzneimittelforschung 25:947-949

9. Yoshioka H, Takimoto M, Riley Jr HD (1974) Pharmacokinetics of ampicillin in the new born infant. J Infect Dis 129:461-464

10. Sutton AM, Turner TL, Cockburn F, McAllister TA (1986) Pharmacokinetic study of sulbactam and ampicillin administered concomitantly by intraarterial or intravenous infusion in the newborn. Rev Infect Dis 8:S518-S522

11. Kaplan JM, McCracken GH Jr, Horton LJ, Thomas MJ, Davis N (1974) Pharmacologic studies in neonates given large dosages of ampicillin. J Pediatr 84:571-577

12. Axline SG, Yaffe SJ, Simon HJ (1967) Clinical pharmacology of antimicrobials in premature infants. II. Ampicillin, methicillin, oxacillin, neomycin, and colistin. Pediatrics 39:97-107

13. Huisman-de Boer JJ, van den Anker JN, Vogel M, Goessens WHF, Schoemarker RC, de Groot R (1995) Amoxicillin pharmacokinetics in preterm infants with gestational ages of less than 32 weeks. Antimicrob Agents Chemother 39:431-434

14. Charles BG, Preechagoon Y, Lee TC, Steer PA, Flenady VJ, Debuse N (1997) Population pharmacokinetics of intravenous amoxicillin in very low birth weight infants. J Pharm Sci 86:1288-1292

15. Pullen J, Stolk LM, Nieman FH, Degraeuwe PL, van Tiel FH, Zimmermann LJ (2006) Population pharmacokinetics and dosing of amoxicillin in (pre)term neonates. Ther Drug Monit 28:226-231

16. Adrianzen Vargas MR, Danton MH, Javaid SM et al (2004) Pharmacokinetics of intravenous flucloxacillin and amoxicillin in neonatal and infant cardiopulmonary bypass surgery. Eur $\mathrm{J}$ Cardiothorac Surg 25:256-260

17. Pullen J, Driessen M, Stolk LML et al (2007) Amoxicillin pharmacokinetics in (preterm) infants aged 10 to 52 days: Effect of postnatal age. Ther Drug Monit 29:376-380

18. Weingartner L, Sitka U, Patsch R, Richter I (1977) Experience with amoxycillin in neonates and premature babies. Int $\mathrm{J}$ Clin Pharmacol Biopharm 15:184-188
19. Pullen J, de Rozario L, Stold LM, Degraeuwe PL, van Tiel FH, Zimmermann LJ (2006) Population pharmacokinetic and dosing of flucloxacillin in preterm and term neonates. Ther Drug Monit 28:351-358

20. Herngren L, Ehrnebo M, Broberger U (1987) Pharmacokinetics of free and total flucloxacillin in newborn infants. Eur $\mathrm{J}$ Clin Pharmacol 32:403-409

21. British Medical Association (2005) Royal pharmaceutical society of Great Britain, royal college of paediatrics. BNF for children. Pharmaceutical Press, London

22. Sitka U, Weingarterner L, Patsch R, Richter I (1980) Pharmacokinetics of azlocillin in neonates. Chemotherapy 26:171-176

23. Heimann G (1983) Pharmacokinetics and clinical aspects of azlocillin in paediatrics. J Antimicrob Chemother 11:127-135

24. Janicke DM, Rubio TT, Wirth FH, Karotkin EH, Jusko WJ (1984) Developmental pharmacokinetics of mezlocillin in newborn infants. J Pediatr 104:773-781

25. Odio C, Threlkeld N, Thomas ML, McCraken GH Jr (1984) Pharmacokinetic properties of mezlocillin in newborn infants. Antimicrob Agents Chemother 25:556-559

26. Fayed SB, Sutton AM, Turner TL, McAllister TA (1987) The prophylactic use of ticarcillin/clavulanate in the neonate. $\mathrm{J}$ Antimicrob Chemother 19:113-118

27. Fricke G, Doerck M, Hafner D, Horton R, Kresken M (1989) The pharmacokinetics of ticarcillin/clavulanate acid in neonates. $\mathrm{J}$ Anticrob Chemother 24:111-120

28. Burstein AH, Wyble LE, Gal P et al (1994) Ticarcillin-clavulanic acid pharmacokinetics with presumed sepsis. Antimicrob Agents Chemother 38:2024-2028

29. Kacet N, Roussel-Delvallez M, Gremillet C et al (1992) Pharmacokinetics study of piperacillin in newborns relating to gestational and postnatal age. Pediatr Infect Dis J 11:365-369

30. Craig WA (2001) The hidden impact of antibacterial resistance in respiratory tract infection. Re-evaluating current antibiotic therapy. Respir Med 95[Suppl A]:S12-S19 discussion S26-27

31. Drusano GL (2004) Antimicrobial pharmacodynamics: critical interactions of 'bug and drug. Nat Rev Microbiol 2:289-299

32. Cars O (2001) Steering an appropriate course: principles to guide antibiotic choice. Respir Med 95[Suppl A]:S20-S25

33. de Hoog M, Mouton JW, van den Anker JN (2005) New dosing strategies for antibacterial agents in the neonate. Semin Fetal Neonatal Med 10:185-194

34. Warrier I, Du W, Natarajan G, Salari V, Aranda J (2006) Patterns of drug utilization in a neonatal intensive care unit. $\mathrm{J}$ Clin Pharmacol 46:449-455

35. Narayan S, Mathai SS (2005) Antibiotic use in neonates of birthweight $<2000 \mathrm{~g}$ surviving to discharge. Med J Armed Forces India $61: 342-344$

36. Ekelund K, Konradsen HB (2004) Invasive group B streptococcal disease in infants: a 19-year nationwide study. Serotype distribution, incidence and recurrent infection. Epidemiol Infect 132:1083-1090

37. Siegel JD, McCracken Jr GH, Threlkeld N (1980) Single-dose penicillin prophylaxis against neonatal group B streptococcal infections. A controlled trial in 18,738 newborn infants. N Engl J Med 303:769-775

38. Patel DM, Rhodes PG, LeBlanc MH, Graves GR, Glick C (1999) Morrison J Role of postnatal penicillin prophylaxis in prevention of neonatal group B streptococcus infection. Acta Paediatr $88: 874-879$

39. Tessin I, Trollfors B, Thiringer K, Larsson P (1991) Ampicillinaminoglycoside combinations as initial treatment for neonatal septicaemia or meningitis. A retrospective evaluation of 12 years' experience. Acta Paediatr Scand 80:911-916 
40. Choonara I, Rieder MJ (2002) Drug toxicity and adverse drug reactions in children - a brief historical review. Paediatr Perinat Drug Ther 5:12-18

41. Shaffer CL, Davey AM, Ransom JL et al (1998) Ampicillininduced neurotoxicity in very-low-birth-weight neonates. Ann Pharmacother 32:482-484
42. Clark RH, Bloom BT, Spitzer AR, Gerstmann DR (2006) Empiric use of ampicillin and cefotaxime, compared with ampicillin and gentamicin, for neonates at risk for sepsis is associated with an increased risk of neonatal death. Pediatrics 117:67-74

43. Neonatal Formulary 3 (2000) Northern neonatal network. BMJ Publishing Group, London 